\title{
Persuasive Messages Effect of @ bittersweet_by_najla Instagram Account on Customer Perceptions September 2020 Period
}

\author{
Michaela Felicia ${ }^{1}$ Diah Ayu Candraningrum ${ }^{1 *}$
}

\author{
${ }^{1}$ Faculty of Communication, University Tarumanagara, Jakarta 11440, Indonesia \\ ${ }^{*}$ Corresponding author. Email: diahc@fikom.untar.ac.id
}

\begin{abstract}
This study aims to determine the persuasive messages effect of @bittersweet_by_najla's Instagram account on customer perceptions September 2020 period. The theory used in this study is the theory of persuasive communication, persuasive messages, and perceptions. The research method used in this study is quantitative approach with a survey method. Data collection was carried out by distributing questionnaires to 100 samples of customer respondents who followed the @ bittersweet_by_najla Instagram account. Then, the validity of the data obtained was tested by validity and reliability tests. The technique of processing and analyzing the data of this research uses classic regression assumption test, simple regression analysis, correlation coefficient analysis, determination coefficient analysis, and $t$ test. The results showed that there was an effect of persuasive messages on @ bittersweet_by_najla Instagram account towards customer perceptions for the period of September 2020, with the results of the $t$ test showing the $t$ value of 13.669> $1.984 \mathrm{t}$ table. In addition, the result of the determination coefficient test showed the number 0.652 , which means that the persuasive message on @bittersweet_by_najla Instagram account affected customer perceptions for the September 2020 period by $65.2 \%$.
\end{abstract}

\section{Keywords: Persuasive messages, customer perceptions, Instagram}

\section{INTRODUCTION}

According to Morissan [1] the presence of the internet is not only changing designing and implementing a marketing business strategy but also influencing marketing communication programs. In contrast to other forms of marketing communication such as traditional one-way advertising, interactive media makes it possible for users to perform various functions such as receiving and changing information or pictures, answering questions and also making transactions.

One of the social media, Instagram which is not only used to express themselves and connect with things that interest users in entertainment, music, fashion, art and sports. But also used as a platform to promote their business [2]. The online shop named @bittersweet_by_najla which is known as the number one pioneer of dessert box has outlets in Kalibata, Kemang, Bogor, Rawamangun and Depok with more than 867,000 followers on Instagram accounts within September 2020. Dessert box is a dessert (cake) in a box. Unlike the usual dessert served on a plate, dessert boxes can be eaten directly from the place [3].

Instagram is used by @bittersweet_by_najla as a platform to find, connect, and interact with their followers via photos, videos and other features. As it is known, marketing communication must contain information with effective messages in order to reach the right target. In marketing communications, many persuasive messages are produced with goals such as inviting the audience to know and buy or consume certain products [4].

The author sees that the brand loads product information with persuasive messages on Instagram account posts or content that is done in a very interesting way so it deserves to be used as a research topic. In addition, the state of the COVID-19 pandemic which began in early 2020 affects the majority of people carrying out activities from home. This gives higher intensity impact in society accessing everything through gadgets including shopping through social media. Based on this, the authors conducted research on "Persuasive Messages Effect of @ bittersweet by najla Instagram Account on Customer Perceptions September 2020 Period".

\subsection{Research Contribution}

This research can be useful for all parties. The results of this study are expected to add insight and development of communication, especially in the field of public relations concentration on improving the management of social media or information that also contributes to the quality of scientific work completion. In addition, this study is expected to provide input and become a reference for public 
relations practitioners in improving the quality of social media management, especially Instagram.

\subsection{Paper Structure}

The rest of the paper is organized as follows. Section 2 introduces the preliminaries used in this paper, which include the framework and theory used in the research. Section 3 to 4 presents the research method and data analysis. Then, section 5 concludes the paper and presents direction for future research.

\section{BACKGROUND}

Effendy stated that paradigmatically communication is the process of delivering a message by someone to another to inform or to change attitudes, opinions or behavior, either directly, orally or indirectly through the media. One of the communication techniques is persuasive communication, which is the process of delivering messages from communicators to communicants in the purpose of changing attitudes, opinions, and behavior on their own awareness. Every communication activity carried out by humans has its own technique. Technique is a way to convey or show information that is done so that it can be understood by other people well. There are four types of communication techniques described by Effendy [5], such as informative communication, persuasive communication, instructive/coercive communication, and human relations. Persuasive communication techniques certainly use the form of persuasive messages because in the world of marketing, especially social media, persuasive messages are the most frequently used as an attempt to change attitudes, opinions and behavior of customers. The compilation of persuasive messages has a proposition or a what the desired source against the recipient as a result of the message delivered.

Based on the research model of Chang, Yu and $\mathrm{Lu}$ [6], persuasive messages contain at least three points, the argument quality, posts popularity, and post attractiveness. Therefore, argument quality is the value of the message perceived by consumers and a strong quality argument can generate positive thinking by message recipients. The popularity of a post refers to the number of likes, comments, shares, response forms and comments on a message according to De Vriesa, et al. Besides that, Ahearne, Gruen, and Jarvis [7], stated that posts attractiveness refers to the way recipients see the post as a worthy appealing post.

The communication technique in this study focuses on communication in the form of persuasive messages because in the world of marketing, especially social media, persuasive messages are most often used as an effort to change customer attitudes, opinions and behavior. Through social media, users can produce and share content that contains information to the other users. In social media, there is freedom for users to produce content according to user preferences and can be distributed directly via devices such as smartphones and computers connected to the internet [8].
A person's perception of the stimulus or how it was received will be different from one another [9]. Simply put, perception which is formed is determined by the person who receives and responds to the stimuli. Perception formation is divided into three processes Kotler and Keller in Febrida [10], such as selective attention, selective distortion, and selective memory. Selective attention is a process that happens when the customer receives a lot of stimuli (messages) which then automatically filters the message they got. Selective distortion is the tendency of the customer translating information according to its own way or concept of thinking. Selective memory is a process in which customers only remember information that supports their personal feelings and beliefs.

\subsection{Framework}

Figure 1 Framework

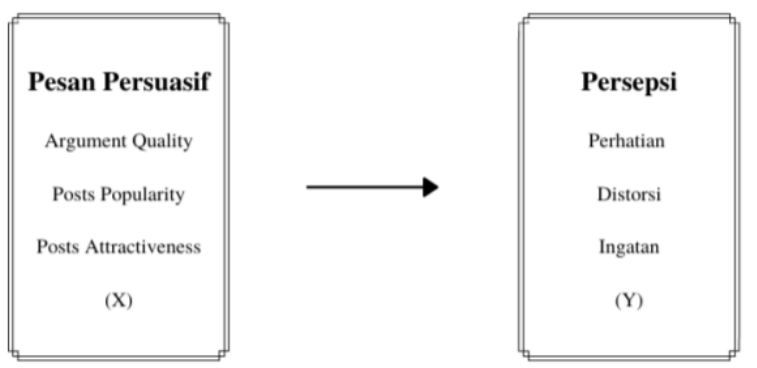

According to Figure 1, the following hypothesis can be drawn:

$\mathbf{H}_{0}$ : Persuasive messages on Instagram account @bittersweet_by_najla do not affect customer perceptions. H$_{1}$ : Persuasive messages on the @ bittersweet_by_najla Instagram account affect customer perceptions.

Based on the framework, it can be identified that there are two variables in the research framework, persuasive message variable $(\mathrm{X})$ as the independent variable and the perception variable (Y) as the dependent variable. The prediction pattern of the relationship between variables in the research framework is indicated by a one-way arrow, which means that the variable is hypothesized to have a causal (cause-effect) or asymmetric relationship.

\section{METHODS}

In general, this research approach or often called the research paradigm are divided into quantitative research paradigm and qualitative research. Quantitative research emphasizes objective phenomena and is studied quantitatively. The maximization of the objectivity of the research design was carried out using numbers, statistical processing, structure, and controlled experiments [11]. This study uses a quantitative research approach. A quantitative approach is used to determine whether there is a correlation or influence of the independent variable on the dependent variable [12]. The variables to be examined in this study 
include persuasive message as the independent variable and perception as the dependent variable.

Creswell divides the research methods into eight types such as, experimental design, correlational, survey, grounded theory, narrative research, mixed methods, and action research. The first three designs are quantitative research. Quantitative research methods are grouped into two main methods as experimental and non-experimental methods. This study used a non-experimental method, namely the survey method. A survey is a study using people's answers as research data. Data collection is obtained through a series of questions designed in the form of a questionnaire and then distributed to the sample [13].

In this study, researchers distributed questionnaires via google form to @ bittersweet_by_najla customers to obtain data related to the research topic. The data obtained were then analyzed using statistical tests in order to find the facts of each variable studied and to know the effect between the independent and dependent variables.

\subsection{Population and Samples}

The population of this study are customers or followers of @ bittersweet_by_najla Instagram account which has been active since 2016 communicating messages or viewing their content. The total population is 861,000 followers within the September 2020. This study uses a non-probability sampling technique with purposive sampling technique based on certain considerations or criteria. The questionnaire will be distributed to the sample with the following criteria, (1) Customers who have followed the Instagram account @bittersweet_by_najla since early 2020 until now, (2) Are over 17 years of age, and (3) Aware of @ bittersweet_by_najla posts or content on the Instagram account. By using the Slovin formula, the number of samples taken is 99.98 people rounded-off to 100 Instagram account followers @ bittersweet_by_najla.

\subsection{Data}

The data in this study was carried out by distributing questionnaires via google form to 100 respondents who follow the @bittersweet_by_najla Instagram account. In addition, the authors also conducted literature studies, and collected data related to the research topic through several book references obtained from public libraries and online sources.

\subsection{Validity and Reliability}

Data obtained from respondents are processed using IBM SPSS Statistics 23 to prove indicators that represent persuasive message variables and perceptions variables in the questionnaire.

\subsection{Data Analysis}

In this study, the data obtained were analyzed using the classic regression assumption test, simple regression analysis, correlation coefficient analysis, determination coefficient analysis, and $\mathrm{t}$ test. Classical regression assumption test using the normality test technique to confirm the data collected has confounding variables that are distributed normal. If it is normally distributed or close to normal, then the data is considered suitable for use because it represents the existing population [14]. Simple regression analysis was used to assess or measure the predictive power of one independent variable towards one dependent variable [15].

Correlation coefficient analysis is used to calculate the closeness degree of the relationship between two variables. The statistical technique of calculating the coefficient of determination is to look for the effect of variable variance on other variables [16]. Then, the partial testing technique ( $t$ test) aims to test if there is a significant relationship between variable $\mathrm{X}$ and variable $\mathrm{Y}$.

\section{FINDINGS AND DISCUSSIONS}

Through 100 questionnaires distributed to research samples, consist 10 indicators of persuasive message variable $(X)$ as the independent variable and 8 indicators of perception variable $(\mathrm{Y})$ as the dependent variable. In total, there are 18 statements in the questionnaires. The gender percentage of @bittersweet_by_najla Instagram account followers taken as a respondent. The majority of respondents were women, as many as 89 people, while the rest 11 respondents were male.

From 100 respondents there were 77 respondents aged 17 to 21 years, 21 respondents who were aged between 22 to 26 years, and as many as 2 respondents aged between 27 up to 31 years. There are 35 respondents who access @ bittersweet_by_najla Instagram account one to three times a day, 55 respondents who access @ bittersweet_by_najla Instagram account one to three times in a week, and 10 respondents who access @bittersweet_by_najla Instagram account one to three times in a month.

The results of data obtained are used to test the validity and reliability. The validity calculation was carried out by researchers using the Google Spreadsheets and IBM SPSS Statistics 23 software. The validity test was carried out on 100 respondents with a significant level of $5 \%$ and the $\mathrm{R}$ table was 0.165 which stated that the statements distributed by the number of 18 statements were valid. While the calculation of reliability using the Cronbach Alpha formula uses IBM SPSS Statistics 23. A construct or variable said to be reliable if it provides a Cronbach Alpha value $>0.70$ [17]. Reliability testing was conducted with a significance level of 5\%. The 18 questionnaires distributed by the researcher to respondents were considered reliable because the $\mathrm{X}$ variable with the Cronbach Alpha value was 0.861 and the $\mathrm{Y}$ variable was 0.877 above 0.70 . 
Table 1. Result of t test

\begin{tabular}{|c|c|c|c|c|c|c|}
\hline & & \multicolumn{2}{|c|}{ UC* } & \multirow{2}{*}{$\frac{\text { SC*** }}{\text { Beta }}$} & \multirow[b]{2}{*}{ t } & \multirow[b]{2}{*}{ Sig. } \\
\hline & Model & & $\begin{array}{c}\text { Std. } \\
\text { Error }\end{array}$ & & & \\
\hline 1 & (Constant) & $-3,433$ & 2,649 & & $-1,296$ & 0,198 \\
\hline 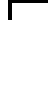 & $\begin{array}{l}\text { Pesan } \\
\text { Persuasif }\end{array}$ & 0,838 & 0,061 & 0,810 & 13,669 & 0,000 \\
\hline
\end{tabular}

*Unstandardized Coefficients **Standardized Coefficients

The $t$ test is carried out in order to test whether there is a significant relationship between the independent variables and the dependent variable. To find out the results of the coefficient of determination, these are the following terms: a. If $\mathrm{t}$ value $>\mathrm{t}$ table, then $\mathrm{H}_{0}$ is rejected and $\mathrm{H}_{1}$ is accepted b. If $\mathrm{t}$ value $<\mathrm{t}$ table, then $\mathrm{H}_{0}$ is accepted and $\mathrm{H}_{1}$ is rejected

Based on table 1, the $\mathrm{t}$ value is $13.669>1.984 \mathrm{t}$ table which means $\mathrm{H}_{0}$ is rejected and $\mathrm{H}_{1}$ is accepted. The significance value is $0.00<0.05$ as well, proves that there is a significant influence between the persuasive message variable towards perception variable.

Table 2. Determination Coefficient Test

\begin{tabular}{|c|c|c|c|}
\hline \multicolumn{4}{|c|}{ Model Summary } \\
\hline Model & $\mathrm{R}$ & R Square & $\begin{array}{l}\text { Adjusted R } \\
\text { Square }\end{array}$ \\
\hline 1 & $0,810^{\mathrm{a}}$ & 0,656 & 0,652 \\
\hline $\begin{array}{l}\text { a. } \\
\text { b. }\end{array}$ & \multicolumn{3}{|c|}{$\begin{array}{l}\text { Predictors: (Constants), Pesan Persuasif } \\
\text { Dependent Variable: Persepsi }\end{array}$} \\
\hline
\end{tabular}

The coefficient of determination analysis aims to find the effect of variable variance on other variables. From the analysis of the determination coefficient according to table 2, the value of Adjusted $\mathrm{R}$ Square (determination coefficient) is 0.652 , which means that the persuasive message variable affects the perception variable by $65.2 \%$. The research results as a whole show that the persuasive messages (independent variable) on @ bittersweet_by_najla Instagram account affects the customer perceptions (dependent variable). This is shown by the results of the $t$ test in table 1 which indicates that $\mathrm{H}_{1}$ "Persuasive messages on the@bittersweet_by_najla Instagram account affect customer perceptions" in this study was accepted. In the other way, this means that the perception of @ bittersweet_by_najla customers is significantly affected by persuasive messages on the @bittersweet_by_najla Instagram account.

According to the research by Chang, $\mathrm{Yu}$ and $\mathrm{Lu}$ [6]) in "Persuasive messages, popularity cohesion, and message diffusion in social media marketing", persuasive messages contain at least three points, such as argument quality, posts popularity, and posts attractiveness. These three dimensions, according to the data obtained and processed by researchers, also shows the indicator that has the highest influence is the post attractiveness dimension. This is based on the frequency data which shows that (67\%) respondents strongly agree that the persuasive message on the @ bittersweet_by_najla Instagram account posting is displayed interestingly.

The process of forming perceptions is divided into three processes, namely selective attention, selective distortion, and selective memory [10]. When viewed from the results of the analysis conducted by researchers on respondents' answers, some respondents strongly agree that they experience selective attention, selective distortion, and selective memories on the persuasive messages of the @bittersweet_by_najla Instagram account for the period September 2020. Referring to the answers given by respondents through a questionnaire which then processed the data with the analysis of the coefficient of determination according to table 2, the value of Adjusted $\mathrm{R}$ Square (coefficient of determination) is 0.652 , which means that the persuasive message variable affects the perception variable by $65.2 \%$. The remaining $34.8 \%$ is explained by various factors not examined in this study.

According to research conducted by Febrida [10] with the title "The Effect of Exposure of Ads on Youtube Social Media on Consumer Perceptions (Study of Subscribers for Tiket.com Ads on Youtube)", exposure to advertisements on Youtube social media has a sufficient and positive effect on consumer perceptions. This concurs with this study, but there are differences in research variables. The independent variable in the research conducted by Febrida [10] is exposure to social media advertisements, while the independent variable used in this study is the persuasive message of the @bittersweet_by_najla Instagram account. This research has a common with research conducted by Febrida [10], the effect of an independent variable on customer perceptions.

Based on the results of the analysis and discussion above, it can be concluded that the persuasive message of @bittersweet_by_najla Instagram account for the September 2020 period has strongly affected customer perceptions. Because the results of the correlation coefficient, determination coefficient, and test state that customer perceptions are strongly affected by the persuasive message of @ bittersweet_by_najla Instagram account.

\section{CONCLUSIONS}

Based on the results of the research that the author has obtained, it shows that persuasive messages on the @bittersweet_by_najla Instagram account affect customer perceptions accepted. The significance value in table 2 also proves that there is a significant influence between the persuasive message and perception variables. In addition, the results of the determination coefficient test showed that the persuasive message of the @ bittersweet_by_najla 
Instagram account affected customer perceptions for the September 2020 period by $65.2 \%$.

\section{ACKNOWLEDGMENT}

This work was supported by the Faculty of Communication, University Tarumanagara (02156958723).

\section{REFERENCES}

[1] Morissan, M.A.. Periklanan: Komunikasi Pemasaran Terpadu. Jakarta: Prenada Media Group, 2010.

[2] Wulandari, Dwi., Mengukur Efektivitas Instagram sebagai Social Commerce. April 5, 2019. [Online]. Available: shorturl.at/hlLN5. [Accessed September 17, 2020].

[3] Azanella, Luthfia Ayu.,. Mengenal Apa Itu Dessert Box dan Bahaya Hidden Sugar. September 13, 2020. [Online]. Available: https://www.kompas.com/tren/ $\mathrm{read} / 2020 / 09 / 13 / 120500065 / m e n g e n a l-a p a-i t u-d e s s e r t-$ box-dan-bahaya-hidden-sugar-?page=all. [Accessed January 16,2021$]$

[4] Pandrianto, Nigar dan Sukendro, Gregorius Genep. "Analisis Strategi Pesan Content Marketing Untuk Mempertahankan Brand Engagement". Jurnal Komunikasi, vol. 10, no. 2, December, 2018. [Online]. Available: http://dx.doi.org/10.24912/jk.v10i2.2619 [Accessed January 16, 2021].

[5] Effendy, Onong Uchjana. Ilmu Komunikasi Teori dan Praktek (cetakan ke 28). Bandung: PT Remaja Rosdakarya, 2019.

[6] Yu-Ting Chang, Hueiju Yu dan Hsi-Peng Lu. "Persuasive messages, popularity cohesion, and message diffusion in social media marketing". Journal of Business Research, vol. 68, p. 777-782, December 10, 2014. [Online]. Available: https://doi.org/10.1016/ j.jbusres.2014.11.027. [Accessed: September 18, 2020].

[7] Joo, Jonathan, dkk. "Pengaruh Argument Quality, Posts Popularity, Posts Attractiveness terhadap Preference Pada Pengguna Facebook oleh Mahasiswa/i Fakultas Ekonomi Universitas Tarumanagara". Conference on Management and Behavioral Studies, October 12, 2017. [Online] Available: http://cmbs. untar.ac.id/images/prosiding/2017/Jonathan-Joo_ Herlina-Budiono_Hendra-Wiyanto-dan-HenryantoWijaya.pdf. [Accessed September 30, 2020].
[8] Taufano, Ricardo dan Irwansyah. "Brand Personality Achmad Zaky Sebagai Chief Executive Officer Bukalapak Dalam Media Sosial Instagram”. Jurnal Komunikasi. vol. 12, no. 2, July 2. 2020. [Online] Available: https://journal.untar.ac.id/index.php/ komunikasi/article/view/7268/5822 [Accessed September 30, 2020].

[9] Supratman, Lucy Pujasari dan Mahadian, Adi Bayu. Psikologi Komunikasi. Yogyakarta: Penerbit Deepublish, 2016.

[10] Febrida, Rachel. (Maret, 2020). "Pengaruh Terpaan Iklan di Media Sosial Youtube terhadap Persepsi Konsumen (Studi terhadap Pelanggan Iklan Tiket.com di Youtube)". Jurnal Prologia, vol. 4, no. 1, March, 2020. [Online]. Available: http://dx.doi.org/10.24912/pr.v4i1. 6471 [Accessed September 30, 2020].

[11] Hamdi, Asep Saepul. Metode Penelitian Kuantitatif Aplikasi Dalam Pendidikan. Yogyakarta: Deepublish, 2014.

[12] Mulyadi, Mohammad. "Penelitian Kuantitatif dan Kualitatif serta Pemikiran Dasar Menggabungkannya". Jurnal Studi Komunikasi dan Media, vol. 15, no. 1, April 16, 2011. [Online]. Available: https://dx.doi.org/10.17933/jskm.2011.150106 [Accessed November 14, 2020].

[13] Suryadi, Edi., Darmawan, Deni., dan Mulyadi, Ajang. Metode Penelitian Komunikasi Dengan Pendekatan Kuantitatif. Bandung: PT Remaja Rosdakarya, 2019.

[14] Sujarweni, V. Wiratna. SPSS untuk Penelitian. Yogyakarta: Penerbit Pustaka Baru Press, 2014.

[15] Silalahi, Ulber. Metodologi Analisis Data dan Interpretasi Hasil untuk Penelitian Sosial Kuantitatif. Bandung: PT Refika Aditama, 2018.

[16] Sugiyono. Metode Penelitian Kuantitatif, Kualitatif, dan $R \& D$. Bandung: Penerbit Alfabeta, 2019.

[17] Ghozali, Imam. Aplikasi Analisis Multivariat dengan Program IBM SPSS. Edisi 7. Semarang: Penerbit Universitas Diponegoro, 2013. 